\title{
Analysis of Learning Difficulties Learning Cultural Arts as a Form of Creativity for Elementary School Students
}

\author{
Lia Mareza \\ \{liamareza@ump.ac.id $\}$ \\ Universitas Muhammadiyah Purwokerto, Purwokerto, Indonesia
}

\begin{abstract}
Practical learning Cultural arts as a form of creativity is learning that brings students to learn arts and culture creatively. Creativity learning can encourage students to learn effectively and get maximum results, both in class and in competition achievements. This study aimed to determine the analysis of learning difficulties in teaching arts and culture as a form of creativity for students with special needs in elementary schools. The research used descriptive research with a qualitative approach. The research subjects were students and teachers of SD Negeri 1 Tanjung Purwokerto. Samples were taken using saturated sampling, namely, using all members of the population as a sample. The data analysis method used is descriptive qualitative.The results showed that learning cultural arts was learning at SD Negeri 1 Tanjung Purwokerto in many methods, because of the form of creativity need cooperation between teachers and students in the implementation of learning, such as lots of students did not understand the material, doesn't send an assignments according to the teacher's time, and didn't paying attention to the teacher when explaining the material. Learning plans are made based on competency standards and necessary competencies. Teachers should have used various methods combined with theory and practice according to the material so that cultural arts learning in class runs optimally. Creativity learning difficulties can be seen in the achievement of students in each assignment made. Still, only a few students are motivated to participate in competitive activities because it is influenced by inhibiting factors from students, teachers, support from parents, and infrastructure.
\end{abstract}

Keywords: Difficulties Learning, Creativity, Elementary School

\section{Introduction}

Education is a determining factor in the success of human resource development. Education is used to develop individuals, especially students, to achieve the necessities of life. Besides, education is used to introduce students when they go to the community to be ready to face existing problems and know how to solve them. In this era, the curriculum must equip students with various competencies, which are used to meet the challenges that exist. The competencies needed in this era must be following global developments, such as communication skills, critical thinking skills, creative thinking skills, intelligence according to talents and interests, have a sense of responsibility towards the environment, and have a broad interest in life. Following the contents of educational objectives, including the development of each individual's potential, 
such as attitudes, knowledge, and skills, children are equipped with knowledge about theory and skills. Creativity is very much needed in terms of education, society, and culture.

Creativity reflects divergent ways of thinking, namely, the ability to provide various alternative answers. The invention can be used to predict learning success [1]. Learning activities should be a bridge to producing creative works because it is a continuous process in education to form vital and creative resources. [2], Many groups made various efforts to stimulate children's creativity from an early age, starting from before birth (prenatal), infancy to children's schooling. For example, music, art, various types of games, and books stimulate children's creativity. Children are already fluent in finding and expecting information from their surroundings. According to [3], elementary school children aged 7-12 years of development are thinking at the concrete operational stage. Children at this stage need physical experiences such as manipulating tangible objects to form their logical thinking experiences. At this stage, the child can think logically but still needs concrete things according to their imagination and desires to understand abstract concepts. For this reason, creativity needs to be nurtured and developed from an early age, especially at the elementary school age, because at these ages, there is a "critical period" in addition to the "peak period" for the development of creativity.

Each individual has different potentials and talents; for example, singing skills can be developed by learning the art of music, dancing can be acquired through learning dance, and painting skills developed in fine arts learning. These skills are integrated into the subject of Cultural Arts and Crafts (SBdP). Cultural arts and crafts education is given to elementary school students to foster students' love for Indonesia's cultural arts. Cultural arts learning also plays a role in shaping the personality of students by paying attention to individual development in achieving the right brain balance, which includes intrapersonal intelligence, visual-spatial, musical, linguistic, mathematical logic, naturalist and adversity intelligence, creativity, spiritual and moral, as well as emotional intelligence. Creativity learning is also an entertainment subject for students because students can be creative and express themselves according to what they want as outlined in work.

[4] also stated that school-age is the effective years in human life to develop creativity. Children's potential at that age is significant for their development to be stimulated to ensure that psychological freedom is maintained. [5] stated that the environment expected to be able to realize children's creativity is family and school. Schools that are expected to provide an educational atmosphere to develop children's creative talents are trapped in optimizing only one aspect, namely training in knowledge, thinking logically / reasoning, and memorizing, so that creativity during school children is the less developed world of education. Cultural Arts and Skills as one of the fields of study in learning by looking at the background will foster competitive moral intelligence. This background is as follows: the content of arts and culture and skills as mandated in the Government of the Republic of Indonesia Regulation Number 19 years 2005 concerning National Education Standards is not only in one subject because culture itself covers all aspects of life. In Cultural Arts and Skills, cultural elements are not discussed separately but are integrated with art. Therefore, the subject of Cultural Arts and Skills is a culture-based arts education.

Fine arts activities are activities in the art area that are non-academic, fun, and flexible. Through art activities, children with special needs become active because children explore various media. The media here is a material or means of creating a work of art. Fine art activities will not make children feel bored and lazy. In this activity, children will be busy making new things and using their imagination to create something unique. [6]. Cultural arts and skills education is given in schools because of the uniqueness, meaning, and benefits of students' development needs. Which lies in providing aesthetic experiences in the form of 
expressive/creative activities through the approaches: "learning with art," "learning through art," and "learning about art." Other subjects cannot give this role. Arts and Culture and Skills Education have a multidimensional and multi-development ability to express oneself creatively in various ways and media such as visual language, sound, motion, roles, and multiple combinations. Multidimensional means developing multiple competencies, including conception (knowledge, understanding, analysis, evaluation), appreciation, and creation by harmonizing the elements of aesthetics, logic, kinesthetic, and ethics. The multicultural nature implies that art education fosters awareness and appreciates various cultures of the Archipelago and Abroad. Cultural Arts and Skills Education have a role in the personal formation of students who are harmonious with attention to the development needs of children in achieving multicultural intelligence, which consists of intrapersonal, interpersonal, visual-spatial, musical, linguistic, mathematical logic, naturalist, and adversity intelligence, creative intelligence, spiritual intelligence and moral, and emotional intelligence [2].

Learning art can encourage students to express their understanding of the subject matter through art forms. Art can train students' imaginative abilities and develop potentials that produce works and increase students' creativity. Being creative does not only apply to artists, but creativity is essential for all fields of knowledge. Art education's position and function are equalized with other subjects in teaching to foster students' sensitivity. Provide the opportunity to develop the competencies and personal potential of students. Besides, art education can increase potential regional capabilities by producing works of art. Regulation of the Minister of Education and Culture of the Republic of Indonesia Number 79 of 2014 concerning Local Content of the 2013 Curriculum states that: Cultural arts education covers various aspects of life. The essential competencies of local content relating to arts, culture, and skills are integrated into cultural arts and crafts subjects. Cultural arts education positions students as heirs to the nation's creative and intellectual intelligence. In skills, outstanding arts, children can develop their interest in working in works in objects.

The National Education Association (NEA), which is an association of professional educators, sets the goals of fine arts education, namely that children can develop an appreciation for beauty, increase their creativity, develop a vision, and develop the ability to voice aspirations [7]. Also, art education equips students in making or creating works with the skills they learn. Educators can develop students' talents in working on Cultural Arts and Crafts; this subject includes learning music, dance, and fine arts. Fine arts learning emphasizes the needs and habits of students in their daily work. In practice, educators can adjust learning to the goals of art education in their schools. Elementary school-age children have different aesthetic characteristics from adults based on their distinctive features. Appreciatively, elementary school-age children have been able to capture the vibrations of a sense of beauty that comes from outside, even though it is very subjective and depends on their respective tastes. This means that students can understand, observe, and feel beautiful things around them. Elementary school-age children have characteristics in doing artworks. Students work on what they want to create according to their feelings, such as sadness, happiness, fantasies, and daily stories. What students often see, how emotions and results of imagination become a strong influence in creating works. Educators are expected to guide students to develop ideas and ideas that students have and put them into position and make students' level of creativity in facing the obstacles they experience when the learning takes place.

The development and implementation of a competency-based curriculum are among the national education development strategies in Law Number 20 of 2003 concerning the National Education System. In this regard, educational institutions have an essential role in developing the creativity of their students. Currently, some educators have convergent thoughts without 
providing opportunities for students to create ideas that students have. Educators will be able to develop creativity in their students if educators also get used to thinking creatively. Conversely, if educators are accustomed to convergent thinking, creative thinking development will be challenging to achieve.

Researchers have conducted interviews with class teachers at SDN 1 Tanjung Purwokerto. From the interviews conducted by researchers with the principal of SDN 1 Tanjung Purwokerto, it can be explained that SDN 1 Tanjung Purwokerto has used the 2013 curriculum as its learning curriculum. In this curriculum, there are subjects of Cultural Arts and Crafts where implementing learning, especially in art, is carried out based on educators' abilities and the availability of existing infrastructure. The competence of educators who do not have a background in the arts makes educators teach art learning according to their abilities. In practice, if the material is deemed challenging to teach students, educators only teach material according to their abilities. The limited-time in SBdP subjects for 2 hours of lessons ( 70 minutes) is considered less efficient in teaching the material. Learning SBdP, which is placed at the beginning or in the middle of learning, makes the class atmosphere not conducive. Although cultural arts learning has many obstacles, SDN 1 Tanjung Purwokerto is quite accomplished. Learning difficulties are conditions of children with average intelligence abilities. Still, they have learning disabilities or failures related to obstacles in the process of perception, conceptualization, language, memory, and concentration of attention, self-control, and sensory integration functions - 5 motor [8]. Students still have difficulty expressing or visualizing works of art in learning cultural arts and skills. Students also tend to imitate existing work without any guidance in terms of object selection and color use. The teacher has not been guided to provide a stimulus for students to draw according to their imagination and inspiration; apart from this, the teacher does have obstacles in giving instructions and directing the making of artwork following the object he chooses. The teacher's nature only follows and adjusts the work in the book, then accepts and evaluates it without any form of evaluation or appreciation from the teacher of the student's work.

From the obstacles in implementing fine learning arts in class, it is hoped that educators will provide solutions or follow-up following class conditions. The condition of the type that is meant is that educators must adjust the material with students' characteristics; besides that, educators must be able to provide innovations in existing learning to feel interested and active during the learning process. Educators need to increase the creativity of students. Therefore educators must also think creatively in developing existing education. The research will focus on the implementation of cultural arts learning in developing the creativity of students. Based on existing data, researchers ask how cultural art learning performance at SDN 1 Tanjung Purwokerto. Of course, in the learning process, there are so many things that can be analyzed from this situation, from the existence of the factors that hinder the implementation of learning above, how the follow-up is given by the educator in overcoming existing problems. Every educator can develop learning according to the creativity level of students. Based on the background, the researchers are interested in studying the simple cultural performances implemented in Crafts. This study only limits how the implementation of cultural arts learning, especially Fine Arts, in developing creativity student the educator gives the follow above, and the researcher is interested in researching the can difficulties in learning cultural arts as a form of student with special needs creativity at SDN 1 Tanjung Purwokerto, which is very important to do. For this reason, the researcher feels it is essential to analyze learning difficulties in learning cultural arts as a form of student creativity at SDN 1 Tanjung Purwokerto. 


\section{Method}

The research method used in this research is descriptive qualitative because it aims to describe learning difficulties and creativity and the local content of cultural arts learning in teacher and student and local cultural values related to the learning content. The local culture in this research is Indonesian cultural values. Research subjects are parties who are used as samples in a study. The subject's role is to provide feedback and information regarding the researcher's data and provide input to the researcher, either directly or indirectly. Researchers chose research subjects in the form of objects, namely teachers and students, and informants, including children with special needs, 3 class teachers, one cultural arts and crafts teachers, and three students' parents. This study's variables were learning difficulties, creativity, aspects of the cultural arts learning content, and local culture in elementary school children's lives. Data collection was collected utilizing document recording and interviews. The documents used include teacher's documents, student books. The interview method was conducted by extracting information from sources (cultural observers, classroom teachers, cultural arts teachers, and parents of elementary school students) about local cultural values.

\section{Results and Discussion}

Indonesia is famous not only for its rich natural resources but also for its rich arts and culture. Six of them have been designated as Indonesian Cultural Heritage recognized by UNESCO, namely Wayang, Batik, Angklung, Saman Dance, Keris, and Papuan Noken. Art is a beauty that humans can enjoy, namely, in the form of activity to convey feelings through work. The function of art itself is as an expression of the human self, apart from that as education. Art in education is to be used as a medium for the education itself because the essence of art is actually related to educational content and is usually directly related to the traditions in each region in Indonesia. Many studies have explored and analyzed cultural arts and the process of creativity for education. [9] with the study results indicate that educators have difficulty formulating goals because the material to be developed is centered on the cognitive and psychomotor domains. Teachers find it difficult to create fabric in a useful direction. The teacher plays an essential role in determining the success of the learning implementation process. Of course, this is an enormous task for education to deepen students' creativity, especially students with special needs. For students with special needs, creativity is significant in their lives so that in the future, they can face the problems of their lives. With high creativity, students with special needs will not experience difficulties and will always be ready to overcome life's obstacles. For example, creative students in doing lesson assignments will always try to make their artwork assignments. With this creativity, strong personalities will emerge in reliable self-identities, selfconsistency, and exemplary personal qualities.

Learning models can also help teachers in implementing cultural arts learning and are very much needed in everyday life as a way to achieve learning goals in the absence of a teacher in the field of arts and cultural studies and assigning teaching assignments in this field of study to teachers whose expertise is not in the areas of arts and culture. Meanwhile, teachers' scope of arts and cultural studies cannot be taught in other study areas. These non-art and cultural education teachers are given the task of teaching arts and culture subjects but are not maximal in their application in doing artwork. Teachers often convey only the theory that is in the student 
textbook. Only the cognitive aspects and learning are described in the classroom to feel bored and bored, less interested in Cultural Arts and Crafts. Even though children are expected to perform specific tasks at every developmental period according to their development level, teachers can adjust by adjusting by planning learning models and methods related to art and culture learning materials. [10] The learning model's purpose is a plan or a pattern used as a guide in planning classroom learning or learning in tutorials and determining learning tools, including books, films, computers, curriculum, and others. The learning model directs teachers in designing learning to help students with special needs to achieve learning objectives. Learning achievement designed in a model can determine its success. Thus the model must have its character and characteristics. [11] argue that the learning model has a broader meaning than strategy, method, or procedure. The teaching model has four unique features that are not owned by process, practices, or systems, for example, as follows:

1. Logical theoretical rationale compiled by the creators or developers.

2. The foundation of thinking about what and how students learn (learning objectives to be achieved)

3. Teaching behavior necessary for the model to be implemented successfully and

4. The learning environment required to achieve the learning objectives. [10].

In educational learning, art bases the production or creation of art on creativity, and to motivate art creation, students and teachers should also be creative. Teacher creativity can be seen in how the teacher prepares the lesson material to not dull. Here the teacher needs to intersperse with a play model or add various media and displays created spontaneously or planned to grow new ideas in creating art. Creativity is a manifestation of a fully functioning individual in the form of himself. This means that students with special needs can develop and use all their talents and abilities and enrich their lives. Creativity allows humans to improve their quality of life. The function of learning cultural arts and crafts is also expected to participate in developing cultural arts and skills in the era of globalization. Art education fosters developing feelings through the production or behavior of art and training in artistic, emotional sensitivity, which contains knowledge about beauty. Teachers' learning approach, so far, has changed the teacher center to a student center-oriented method. Students are the center of attention in learning, while teachers change their function to become facilitators, mediators, motivators. The learning approach's implication with this change of learning paradigm is that teachers and students learn from each other and work together. Therefore, teachers must be open and willing to learn from students, especially students with special needs who have advantages in specific knowledge fields.

Cultural arts teachers must have; (1) a sense of visual art, namely responsiveness/sensitivity to visible symptoms / aesthetic forms, (2) understanding of auditory art, namely responsiveness to the emergence of various audio symptoms, including sound / sound dynamics. And (3) a sense of kinesthetic readiness to respond to the emergence of multiple types of material motion. If the three things above are owned, the art and culture teacher will provide enormous opportunities to develop and find creative ideas for learning arts and culture that are more meaningful and of higher quality. When there are students who have difficulty doing the teacher's assignments, the teacher is very dexterous to help direct, good cooperation between the two teachers in the class makes the classroom atmosphere more effective so that students can understand all the material being taught, and students also become more happy and active in learning, the ability of teachers to use learning media and good mastery of material makes it easier for teachers and students to carry out learning especially arts and culture which practice more. [12] 
The education system needs to be adapted to developing each student's characteristics with special needs in all fields that require different types of expertise and skills and can simultaneously increase creativity. In the learning of Cultural Arts and Crafts, problems are often found about the material or materials needed by teachers and students to be used as material for making works of art as a practice, for example, the theme of activities for making pottery as daily tools, necessary competencies showing appreciative behavior towards Nusantara crafts, student indicators can make crafts. According to the student textbook, the materials used are difficult to find in the student environment. Teachers or students have to buy it somewhere far from their neighborhood. Besides, it is sometimes expensive. So that students with special needs who come from fewer economies cannot afford it. Similarly, it takes time to get it. Therefore, students often do not bring what materials they were ordered to practice learning Cultural Arts and Crafts. This is usually a real condition in schools; besides that, student creativity becomes low, so that the students' artwork is not maximal in this lesson. Based on this, it can be concluded that there must be a solution used as an alternative media for art product material, easy to find in the student environment, inexpensive and safe for children.

Students with special needs have difficulty learning in learning art as a form of creativity. If it is seen from doing their assignments, it is known that students do not all do their tasks, some students make their assignments, and relatives assist some, and those who do groups by friends. Then, suppose it is seen from students' understanding of cultural arts material. In that case, it is known that students understand when the teacher delivers the material, and some students have not expressed their form of creation when the teacher provides material on cultural arts. This is evident that almost all students who are taught cannot explore the artistic skills being taught. This happens because it is caused by several factors, including insufficient learning of concepts, the lack of time allocation provided, the methods used are less varied and not innovative so that it is boring and does not attract students' interest, incomplete learning facilities, and lack of willingness to explore or want to study the material being taught. Knowing difficulties experienced by students with special needs are caused by various factors, which state that the causes of learning difficulties can be grouped into two, namely internal factors and external factors. Internal factors are divided into two kinds of factors, namely physiological factors and psychological factors. Physiological factors related to students' characteristics include aspects of health conditions and the five senses' shape. In contrast, psychological factors include aspects of skills, interest, and motivation. External factors are divided into two kinds of factors, namely social factors and non-social factors. Social factors include family, school, and community, while non-social factors include humidity, study time, weather, school buildings, and learning tools.

Factors that come from within students (internal factors) include motoric abilities, affection such as feelings and self-confidence, motivation, gender, memory abilities, and ability to feel or appreciate. While factors that come from outside students (external factors) include factors related to the learning process, which provides for teachers, learning quality, time and the environment, both social and natural environments. The problem of learning difficulties by [13] is also grouped into two causal factors, namely internal and external factors. Internal factor problems include student characteristics, attitudes towards learning, learning concentration, the ability to process learning materials, the ability to explore learning outcomes, self-confidence, and study habits. At the same time, external factors include teacher factors, social environment, school curriculum, and infrastructure. Characteristics of learning difficulties in art and culture learning materials for children with special needs, namely:

a) Disorders of spatial relations 
The concepts of spatial relationships such as front and back, top-bottom, topbottom, high-low, beginning-end, and far-close are generally mastered by children when they have not entered elementary school. Children have understood the various concepts of these spatial relationships from their experiences communicating with the social environment. Children with learning difficulties often have difficulty communicating. The social environment also usually does not support implementing a situation conducive to communication between children with special needs. Extrinsic conditions in some social settings that do not support the implementation of communication and intrinsic requirements that are thought to be due to brain dysfunction can cause children to experience problems understanding the concepts of spatial relationships, which can interfere with children's understanding of objects and images.

b) Abnormalities in visual perception, children with learning difficulties often have difficulty seeing various items concerning groups or sets. Such a problem is a symptom of abnormal visual perception.

c) Visual-Motor Association, children with learning difficulties cannot count objects in sequence. This kind of child can give the impression that the child has only memorized things without understanding their meaning.

d) Perseveration, there are children whose attention is attached to an object only for a relatively long time. Such attention disorders are called perseveration. Such a child may initially be able to do a task well, but his attention is attached to a particular object over time.

e) Difficulty recognizing and understanding symbols. Children with learning difficulties have difficulty acknowledging and using motifs or ornament symbols. This kind of problem can be caused by memory disturbances but can also be caused by visual perception disorders.

f) Disorders of the body's appreciation, the child has difficulty showing a body image disorder. The child finds it difficult to understand the relationship between the parts of the body on their own. If the child is asked to draw the whole picture, they will pull the body parts in the wrong position.

g) Difficulty in symbolic language and reading. Therefore, language difficulties can affect reading ability to solve them. Therefore, children who have difficulty reading will also experience difficulty in expressing written stories.

h) Performance This intelligence test has two subtests, a verbal test and a performance test. Performance tests include (1) completing images, (2) compiling images, (3) arranging blocks, (4) placing objects, (5) coding.

The results of the author's observations at the beginning found that the arts and culture subjects were only for children who were interested and talented; the arts and cultural issues were held to accommodate the artistic talents of students who were not many. The position of cultural arts subjects is difficult to place as a primary material for intellectual empowerment and the potential for students' creativity. Besides, the fundamental problem in implementing cultural arts learning is the professionalism of cultural arts teachers. Cultural arts teachers must be smart in facing the various issues that occur in learning crafts and culture. To answer these problems is to take advantage of the many available learning facilities and resources. Of course, this is not easy to implement in the form of concrete actions by cultural arts teachers without equipping themselves with an understanding of universal cultural arts insights. Therefore, learning artistic skills must be understood as the fundamental science values that are technical-practical, theoretical, and constructive. Learning art as a skill lesson is considered no longer following 
education with the principles of flexibility, responsiveness, being active, and creativity. Therefore, teachers of cultural arts now have to start reinterpreting and redefining their learning paradigm again. [14]

Students are more excited about the demonstration learning model. The obstacle found in learning cultural arts is when they will do works that require them to imagine themselves. Props are also often an obstacle to work. One simple way this is done is to reduce the lecture method by applying the demonstration method, which is interspersed with the provision of theories relating to the material being taught or currently in progress. The demonstration method that is significantly used supports the increase in student motivation in learning cultural arts because students are more provoked in doing work or imitating and understanding what is shown. Introductory material is given at the beginning of the practice and then conducts the training, interspersed with questions and answers during breaks. The media helps students make a form of work that, initially, students are not interested in using soft materials to become interested. Besides this material is easy to find, the demonstration method is also a way to attract students' interest in creating fine arts.

The availability of competent teaching staff also greatly help used significantly applied motivation in learning cultural arts. Also, the availability of an art space, teaching media, and a supportive family environment is a knowing that the learning process of cultural arts in schools can be carried out correctly and has changed est of students who previously still had less interest and motivation to become more motivated to learn artistic skills. Besides that, students also know the benefits obtained in learning cultural arts. Obstacles that were found, such as a lack of time allocation in cultural arts lessons, can also be overcome using time in the afternoon to continue the material. The method used is also beneficial for students to learn more about the material being taught. Efforts are me student motivation in learning cultural arts, for example, through various learning models.

\section{Conclusions}

Children have understood the various concepts of these spatial relationships from their experiences communicating with the social environment. Children with learning difficulties often have difficulty communicating. The social environment also usually does not support implementing a situation conducive to communication between children with special needs. Besides, the fundamental problem in implementing cultural arts learning is the professionalism of cultural arts teachers. Cultural arts teachers must be smart in facing the various issues that occur in learning crafts and culture. To answer these problems is to take advantage of the many available learning facilities and resources.

\section{References}

[1] Wahyuni. S., 2009. The Influence of Creativity and Learning Frequency on Accounting Learning Achievement in Class XI Accounting Students at SMK Muhammadiyah 2 Surakarta Academic Year 2008/2009. Thesis, Surakarta: UMS.

[2] Ening, Widaningsih. (2012). Learning Cultural Arts and Skills in Developing Moral Intelligence Competitively. Edu Humanities: Journal of Basic Education. Vol. 4. No. 2. Pg. 1-8.

[3] Karli, H. (2010). Reading and writing for early childhood through fun activities and games., No. 15 , Year 9. 
[4] Mulyadi, Seto (2007) Creativity and Play: an experimental study in an effort to develop the creativity of pre-school age children through play activities, with approaches to children and mothers in several kindergartens in Jakarta. Http://www.digilib.ui.a c.id/themes/libri2/detail.jsp?id + = 91309 \& location = local accessed November 1, 2019.

[5] Rismiati, K.A and Wulandari, N. (2004). The effectiveness of reading fiction stories on increasing verbal creativity during school children. Jurnallnsight, 01, 3-18.

[6] Aditya, R. (2015). The Relationship between Reading Interests and Verbal Creativity in Psychology Study Program Students, Batch 2013, University of Mulawarman Samarinda. eJournal of Psychology 596-610.

[7] Retnowati, T. 2010. Modul Pembelajaran Seni Rupa. Universitas Negeri Yogyakarta. https://staffnew.uny.ac.id (downloaded on 6 December 2019).

[8] Riana. A., 2010. A Qualitative Descriptive Study of Social Support for Parents in Elementary School Children with Difficulty Learning to Read in Tambak District, Banyumas Regency. Thesis, Purwokerto: UMP.

[9] Tukirno (2012). Difficulties in the Implementation of Learning in Cultural Arts and Arts Skills in Class V SDN Arjosari 01, Blimbing District, Academic Year 2011-2012. http://karyailmiah.um.ac.id/index.php/seni-desain/article/view/20803 (downloaded on 26 December 2019).

[10] Trianto. 2007. Model-Model Pembelajaran Inovatif Berorientasi Konstruktivisme. Jakarta: Prestasi Pustaka.

[11] Kardi, Soepraman. Mohammad Nur. 2000. Pengajaran Langsung. Surabaya: Universitas Negeri Malang.

[12] Amaliyah 2015 Learning Arts And Culture Using A Scientific Approach At SD Pelita Bangsa Bandar Lampung. Jurnal Seni Dan Pembelajaran. Vol.3. No.1

[13] Aunurrahman. (2010). Belajar dan Pembelajaran. Bandung: Alfabeta.

[14] Edison Simamora, 2019. The Development Of Innovation In The Learning Of Cultural Arts In The Digital Era downloaded on http://digilib.unimed.ac.id/38931/2/atp\%2061.pdf 19 December 2020 